\title{
PRAZER, ESSE SOU ELE (A AUTOBIOGRAFIA POÉTICO-POLÍTICA De André Luiz Pinto)
}

\author{
HI, HIM I AM (THE POETIC-POLITICAL \\ aUtobIOGRAPHy of ANDRÉ LUIZ PINTO)
}

Alberto Pucheu

ORCID 0000-0003-2080-0753

Universidade Federal do Rio de Janeiro Rio de Janeiro, RJ, Brasil

\section{Resumo}

De dentro do eclipsamento da política, a poesia vem se fazendo um lugar de combate contra as totalidades e seus totalitarismos. Parto de uma das principais linhas de força da poesia contemporânea: poemas em que escritos autobiográficos se colocam como políticos através de fraturas que nos fazem pensar feridas, a um só tempo, familiares e comunitárias, íntimas e públicas, atuais e históricas. Enquanto a poesia feita no Rio de Janeiro fora, até certo ponto, realizada predominantemente por moradores da Zona Sul, o local de proveniência do poeta André Luiz Pinto demarca uma intrusão política diferenciada, o subúrbio e o morro, que levam a uma repetiçáo de uma urgência em seus poemas: "A adolescência não sabia/ que apesar da confusão entre prosa/ e poesia, isto não é a revolução. $\mathrm{O}$ que pesa/ é o salário que custeia a vida e a verdade é essa".

Palavras-chave: poesia, política, contemporaneidade, autobiografia, desentendimento.

\section{Abstract}

From within the eclipsing of politics, poetry has become a place of combat against totalities and their totalitarianism. I start from one of the main strengths of contemporary poetry: poems in which autobiographical writings become political through fractures that make us think of wounds that are inflicted to both family and community; intimate and public wounds, current and historical wounds. While the poetry made in Rio de Janeiro was to some extent predominantly carried out by residents of the Southern Zone, the poet Andre Luiz Pinto's place of origin demarcates a distinct political intrusion - the suburb and the slums -,

\section{Résumé}

Depuis l'éclipse de la politique, la poésie est devenue un lieu de combat contre les totalités et leur totalitarisme. Ce travail a pour point de départ l'un des principaux aspects de la poésie contemporaine: les poèmes où les écrits autobiographiques se présentent comme des écrits politiques à travers des fractures qui font penser à des blessures, à la fois familiales, communautaires, privées, publiques, actuelles et historiques. Alors que la poésie faite à Rio de Janeiro était surtout, et dans une certaine mesure, écrite par des habitants de la Zona Sul, le lieu d'origine du poète André Luiz Pinto délimite une intrusion politique distincte, 
which leads to repeteaded urgency in his poems: "Adolescence did not know/ that despite the confusion between prose/ and poetry, this is not a revolution. What matters / is the wage that supports life and this is the truth".

Keywords: poetry, politics, contemporaneity, autobiography, misunderstanding. le faubourg et la favela, qui conduit à la répétition d'une urgence dans ses poèmes: "Ladolescence ne savait pas/ que malgré la confusion entre prose/ et poésie, ce n'était pas une révolution. Ce qui pèse / c'est le salaire qui coûte la vie, c'est cela la vérité".

Mots-clés: poésie, politique, contemporanéité, autobiographie, désaccord.

De dentro do eclipsamento da política, a poesia atual vem se fazendo um lugar de combate contra as totalidades e seus totalitarismos, em nome de uma afirmaçáo contínua da aporia, da divisibilidade e da parte dos sem parcela para que, de dentro do desaparecimento da política, ela possa ter meios em que pode se fazer valer. Como escreveu Rancière, "A atividade política é a que desloca um corpo do lugar que lhe era designado ou muda a destinação de um lugar; ela faz ver o que não cabia ser visto, faz ouvir um discurso ali onde só tinha lugar o ruído, faz ouvir como discurso o que só era ouvido como ruído"1.

Neste ensaio, gostaria de começar a chamar atenção para uma linha de força da poesia contemporânea, poemas que fazem escutar o que, antes, se existente, nem ouvido era: poemas em que escritos autobiográficos de poetas, vinculados à ambiência familiar, dramatizados, não se colocam exclusivamente como pessoais, mas, sobretudo, no âmbito de outra partilha do comum, fazendo com que uma micropolítica se indiscernibilize de uma macropolítica através de fraturas tensas que nos fazem perceber e pensar feridas, a um só tempo, familiares e comunitárias, íntimas e públicas, atuais e históricas, entre, a cada momento, a "parte dos sem parcela" (ou a "parte ou o partido dos pobres" $)$ e as partes poderosamente hegemônicas. Poemas como os de André Luiz Pinto, Tatiana Pequeno, Bruna Mitrano e Danielle Magalhães poderiam ser elencados enquanto alguns dos que, nesse sentido, me parecem representativos.

Privilegiarei André Luiz Pinto, nascido em 1975, cuja estreia se dá no final dos anos 1990. Tendo sido publicado em 2016, o poema que aqui mais diretamente me interessa parece-me um marco por revelar um aspecto determinante e necessário de um certo grupo mais jovem muito considerável de quem faz poesia hoje no Brasil, dando a ela um novo rosto. Como se,

1 RANCIÈRE, Jacques. O desentendimento; politica e filosofia. Tradução de Ângela Leite Lopes. São Paulo: Editora 34, 2018, p. 43.

2 Id.Ibid. p. 26. 
com esse poema, mesmo que não em uma linearidade temporal, A.L.P. possibilitasse uma passagem entre sua geração e a mais nova, a que tenho chamado de Geração Lula, para a qual o ex-presidente e a internet exercem um papel preponderante.

Enquanto que, entre nós, em tempos passados, houve uma predominância de poetas diplomatas e funcionários públicos, enquanto que, mais recentemente, houve uma predominância de poetas que encontraram as aulas na universidade ou em colégio como alternativa de trabalho estabilizandose em uma classe média, a geração mais nova, que vai chegando aos 30 anos ou que passa um pouco deles, é repleta de moças e rapazes que vêm de famílias pobres, do subúrbio, da periferia, de favelas, que foram e são os primeiros de suas famílias a terem condiçóes de estudar em universidades públicas, que tiveram bolsas auxílios, bolsas de Iniciação Científica, bolsas de Mestrado, bolsas de Doutorado, que hoje fazem Mestrado ou Doutorado em Filosofia, História, Letras..., moças e rapazes que, no caso do Rio de Janeiro, deslocam a poesia da Zona Sul, levando-a para outras paragens, outros posicionamentos, outras intervençôes existenciais e políticas.

Nesse caminho, o embaraço, o paradoxo, o impasse, a inviabilidade, a aporia, ou seja, o desentendimento e a dramaturgia do litígio que aqui importam enquanto política é a requisição do "partido dos pobres" participando da contagem do povo, da "parte dos sem parcela" fraturando a totalidade imaginária do antipolítico que não reconhece sua existência. Deslocar, através do litígio, um corpo de seu lugar de invisibilidade ao qual fora condenado, fazendo ser visto e ouvido enquanto um discurso articulado para que possa ser reconhecido, é a política. A questão a ser pensada é como a poesia encena essa dramaturgia do litígio e realiza esse ingresso da "parte dos sem parcela" na contabilidade de uma população. Desta vez, isso será visto em André Luiz Pinto, tomado como um dos possíveis anunciadores dessa transformação decisiva.

Começo com um poema paradigmático, de 2016, que me parece revelar muito dos enormes méritos da poesia contemporânea. Como o poema não tem título, sempre que me referir a ele, usarei o primeiro verso entre aspas para designá-lo.

Prazer, esse sou eu filho de doméstica numa época em que patróes cismavam em chamar de filhas as mucamas. Eu criado numa mansão 
da Barra, obrigado a amar

patróes como avós

sem direito de herança.

Uma coisa aprendi:

a ler livros e a me irritar

com facilidade - lá, onde

o sinal está vermelho

e sempre acabo errando

a baliza - onde ninguém

divide nada, quando

até quem te chamou de sobrinho

diz um dia: a casa é nossa

deves partir. Tá bom, disse.

Só me dá duas semanas ${ }^{3}$.

No respectivo livro, Mas valia, esse poema aparece na página 16, ao lado de outros treze com temáticas diversas. Quem, sem conhecer os outros livros de André Luiz Pinto, ler "Prazer, esse sou eu” exclusivamente em tal contexto, não imaginará a recorrência e a importância decisiva da temática familiar ao longo de sua trajetória, que compreende os livros Flor à margem, de 1999 (produção independente), Primeiro de abril, de 2004 (Editora Hedra), Isto, de 2005 (Espectro Editorial), Ao léu, de 2007 (Editora Bem-te-vi), Terno novo, de 2012 (Editora 7Letras), o mencionado Mas valia, de 2016 (Editora 7Letras) e Nós, os dinossauros, de 2016 (Editora Patuá), além de Poemas, a plaquete de 2018 do evento Vozes, Versos, organizado por Tarso de Melo e Heitor Ferraz, em que o poeta está em companhia de Guilherme Gontijo Flores e Mônica de Aquino.

É bem verdade que apenas em Ao léu começam a surgir poemas em que, repetida e explicitamente, comparecem a mãe, o pai, os filhos, a irmã, oito irmãos (dos quais ele se diz o primogênito), a avó, o avô, os avós também no plural, primos, o sobrinho, a família, a casa familiar, "o olhar da mulher que ama”, Aline (sua primeira companheira, a quem poemas e livros são dedicados), Cláudia (a sobrinha da avó nomeada de Leda Coelho de Faria Rocha ou Dona Leda), Felipe (o nome do sobrinho), o próprio nome André Luiz Pinto, Cris (a atual companheira, a quem poemas e livros também são dedicados), Tales (o filho do poeta)...

A partir do livro de 2007, a explicitação da temática familiar se faz presente em todos subsequentes, tendo, entretanto, uma intensidade especial em Terno novo, de 2012, livro de extrema importância na trajetória do poeta.

3 PINTO, André Luiz. Mas valia. Rio de Janeiro: Editora 7Letras, 2016. p. 16. Coleção Megamíni. 
Se o poema ressaltado dialoga com muitos outros, o vínculo mais direto se dá com os dois primeiros da série "Sete vezes" (especialmente o segundo) e, sobretudo, com os da série "Em família", ambas de Terno novo. Entre este livro e Mas valia (de 2016), nenhum outro fora publicado, deixando entrever que "Prazer, esse sou eu" poderia, ao menos tematicamente, pertencer àquela série mais explosiva que é "Em família". Com sua maturidade distintiva por sua composição extremamente direta e precisa, sem qualquer pirotecnia verbal, com seu tom que resguarda certa coloquialidade medida e elegante, seu testemunho dramatizado em uma simplicidade perfeita contrastando com o incômodo do assunto abordado e sua totalmente inesperada aquiescência final, ele poderia ser um poema chegado tardiamente da série do livro anterior, um poema, apesar do vínculo com os precedentes, deslocado de sua família, necessitando sair de sua casa, precisando de um intervalo de quatro anos e de se posicionar em outro lugar, assumidamente de fora, para estabelecer um novo modo de uma conversa "em família". Há uma diferença significativa desse poema em relação aos da série, que não minimiza em nada a importância dela, mas o engradece ainda mais: nele, não se encontra a menor afetação, nenhum traço do patético.

Com seus doze poemas, "Em família” é uma série única na poesia, um tour de force existencial e poético, uma lida corajosa com o irreparável de uma exclusão, um intenso acerto de contas com o fato de ter sido deixado de fora da família que o criou. Tal série tem uma importância decisiva dentro da poética de A.L.P. e um lugar singular assegurado na poesia brasileira. Há nela, entretanto, elementos que, fazendo-a ter a grandeza que tem, "Prazer, esse sou eu" conseguiu se livrar completamente deles, aumentando, com isso de que ele conseguiu abrir mão, a importância decisiva deste poema exemplar, perfeito no que se propóe a ser enquanto um desdobramento diferenciado de "Em família". Apenas em uma análise muito rigorosa, que quer valorizar "Prazer, esse sou eu", alguns de tais elementos que podem ser encontrados na série, comparando-a ao poema mencionado que deles já se livrou, são algum exagero patético (o primeiro verso do primeiro poema da série já abre afirmando "Caído de joelhos", e, pouco depois, outro verso diz "enterrei-me sozinho"); um uso ou outro de palavras que trariam ao poema uma ênfase previamente garantida na transmissão do que se quer ("esse esgoto para começar”); uma vontade, certamente justa, de vingança (“(como os hipócritas lembram sempre deputados/ de plantão)”, “[...] (Pausa/ Para Cuspir)" - note-se aqui o emprego repetitivo dos parênteses e as maiúsculas para ressaltar o asco); a necessidade de esclarecimento e de explicação reiteradas ("A vida pede esclarecimento/ e esclarecerei”, "e a explicação só poderia ser

4 "Em família" pertence a Terno novo, indo da página 49 à 62 do respectivo livro. 
uma”); frases enfáticas e metáforas em busca de efeitos (“[...] Descendência/ discreta cravada de martírios"); a explicitação em, à revelia de alguns, ser ele o escolhido pela avó falecida ("[...] Ela disse/ que me amava mais que tudo/ e vocês não"); um aparente desprezo pela situação que gera a dor, querendo-a, talvez, disfarçar e mostrar alguma superioridade a quem a provocou ("até porque/ (deu pra notar)// dou/ a mínima”); uma tentativa de mostrar uma generosidade, mesmo que possivelmente irônica ("Queria dizer também e agradecer/ a Cláudia/ que se lembrou/ de minh'avó”); uma necessidade de deixar claro que não quer participar da partilha dos bens da herança ("Fiquem com Búzios/ queimem seu lar que Leda não mora mais")...

$\mathrm{Na}$ trajetória de A.L.P., há, sobretudo, uma poética do desamparo, uma poética do desabrigo. Há uma perda, uma exclusão, um deixar de fora, uma quebra, uma tristeza, uma dor, uma rascância assumidas nesses poemas que querem desdobrá-las, dar-lhes voz, afetos, linguagem, pensamentos. Privilegiando algumas passagens predominantemente familiares, esta é uma poesia para a qual: "[A casa possui] rosas e patifes que não escolhemos", "A miséria começa em casa,/ com seus filhos, a lamúria cega mas certa/ de seu pai", "pai tinha/ dessas manias/ como de quebrar garrafa/ enquanto fechava/ a porta", "Taí/ o chicote/ que você usava/ ao menor/ barulho","sei que teu primo morreu, o réu da acusação um outro/ que fora primo, chamávamos primo e ele nos abençoava com sua gargalhada/ como acusar um primo para inocentar um outro", "[...] o ventre/ da tua mãe balofa não ia dar boa/ coisa mesmo", "Ontem não foi feliz", "Essas são/ as esporas./ Ninguém lhe trará rosas", "Qual a marca/ do ódio dessa cicatriz?”, "Quando Aline enlouquece, sou eu que fico de fora./ O mundo parece fadado// ao fracasso, ainda mais com o soluço dessa criança", "Certo que não há como antever/ o silêncio na boca de teu pai./ Canalha, uma dose de cinismo", "Silenciosa, bem-vinda é a vida/ que lhe obriga a andar de quatro", "Do meu tio/ lembro de meu pai/ dizer 'o cara não presta'/ Zé, vai por mim/ ninguém" 5 ...

Há toda uma dramaturgia lírica familiar sendo encenada, improvisada pelo cuidado áspero de uma dramatização poética da aporia de sua exclusão familiar, da aporia entre o pertencimento e o não pertencimento à família. É preciso ao poeta lidar com um "claríssimo náo"6, sendo levado a realizar uma partida que, dizendo sim à sua história, garanta sua alteridade e distância. No que diz respeito ao autobiográfico familiar, a poesia de A.L.P. deseja chegar o mais próximo possível do traumático do real, do temível, a ser encarado, de um real, terrível, a ser suportado, de um real que teima a um só tempo atormentar e a se esquivar, demandando um retorno intensivo a ele que deixa,

5 Passagens tiradas de poemas espalhados ao longo de sua obra.

6 PINTO, André Luiz. Primeiro de abril. São Paulo: Editora Hedra, 2004, p. 45. 
entretanto, rastros decisivos. Diante do fato de que "[...] todos, como nós, abafam/ os casos", como olhar o "pior", como olhar "se viesse do fundo uma outra verdade/ submersa"? ? Diante do "pôr panos quentes/ [...] no podre/ das famílias", como permitir a eclosão desse podre, dessa "[...] escandalosa/ e ultrajante/ [a] verdade" ? Como olhar essa outra verdade submersa, ultrajante e escandalosa, que emerge avassaladoramente do fundo? Como olhar "palavras [que] continuam ao léu/ de onde se arrancam histórias/ das mais fundas raízes" 10 ? Não me parece à toa que, também em Terno novo, haja um poema intitulado "Retorno"11 que, desde sua primeira palavra, traz um imperativo que retorna sete vezes em seus dezoito versos: "Olhe". "Olhe", diz o poema de forma retornante, fazendo com que seja esse próprio imperativo que retorna: "Olhe a tua volta", "Olhe a tua volta", "Olhe ao redor", "Olhe mais um pouco", "Olhe, peço de novo", "Olhe", "Olhe bem de perto". Ao fim das repetiçóes imperativas e demandadoras, esse "Olhe bem de perto" vem com um acréscimo que diz muito dessa poesia: "Olhe bem de perto, você aguenta". Suportar o que há para encarar, suportar um mundo triste que se herda olhando-o bem nos olhos, sofrer o que se vive e o que para poder se compreender se olha, parecem ser a demanda e a coragem da poesia de A.L.P..

Já foi dito que é apenas em Ao léu, seu quarto livro, que começam a surgir poemas em que, repetida e explicitamente, há uma encenação ou uma poetização de uma autobiografia familiar política. Há algo nesse livro que chama imediatamente atenção e será decisivo na geração vindoura, a que, como disse, tenho chamado de Geração Lula, a de quem nasce em torno dos anos 1990, começando a publicar na segunda década dos anos 2000. Enquanto, até certo ponto, a poesia brasileira fora realizada predominantemente por moradores da Zona Sul - basta dar uma rápida olhada na chamada Geração Marginal ou Mimeógrafo para se ter a confirmação disso ainda nos anos 1970 -, o local de proveniência poeticamente declarado de A.L.P. demarca uma intrusão política diferenciada. Uma outra parte, até entáo praticamente inaudita, requisita-se então para a contagem poética e política. Estabelecendo uma outra regiáo - e uma outra maneira de vida - a ser explorada, o primeiro poema do livro diz com clareza a que vem. Sua segunda estrofe é clara: "Onde minha mãe nascera/ minha avó morrera/ o subúrbio não se cansa de dizer/mais esquecido que o nordeste" 12 . Nessa espécie de genealogia familiar

7 Id.Ibid.p. 15.

8 PINTO, André Luiz. Terno novo. Rio de Janeiro: Editora 7Letras, 2012. p. 60.

9 Id.Ibid. p. 58.

10 Ibid. p. 31

11 Ibid. p. 14.

12 PINTO, André Luiz. Ao léu. Rio de Janeiro: Editora Bem-te-vi, 2007.p. 9. 
feminina, privilegiando, portanto, uma linhagem matriarcal ao patriarcado, a linhagem que provém da avó se estende pela mãe para delimitar o lugar de proveniência e origem, o lugar mais esquecido politicamente de todos os lugares, mais esquecido ainda do que o Nordeste até o começo dos anos 2000 (o Nordeste deixará de ser lembrado exclusivamente pela seca, pela mortalidade infantil, pelos retirantes e por sua miséria apenas no governo Lula): o subúrbio.

Nessa genealogia, logo depois da avó e da mãe, o próximo a entrar em cena, na estrofe imediatamente seguinte, é ele, o poeta: "Escrever é proibido, artistas vivem/ de pagode, bate aqui no peito/ a ruína de quem cedo/ aprendeu a ler e eu não devia"' ". Longe da contracultura dos anos 1970 da Zona Sul e das praias cariocas, em que, com o desbunde, a permissividade era requisitada e proibido era proibir, esse que provém do subúrbio nasce sob o signo de uma restrição, de uma proibição, de uma lei: "Escrever é proibido". A quem vem do subúrbio e de suas condiçóes de vida, o imperativo é, desde cedo, o trabalho imediato pela sobrevivência. Em uma "Madureira, matadouro de homens"14, como dito na última estrofe do poema, lutar, em vários níveis, pela sobrevivência, para não ter sua vida reduzida a uma vida animal, a uma vida nua, destinada a ser conduzida à morte. No subúrbio de mortes e assassinatos, no subúrbio que mata, nesse "matadouro de homens", se, apesar de tudo, for possível ser artista, que se seja artista de uma arte popular musical, que até pode vir a ser remunerada e passar completamente por fora da leitura e da escrita. Lembro, ainda, a repetição dessa urgência econômica no poema "iv" de "Em família", que, lidando já com a leitura e com a escrita, começa dizendo: "A adolescência não sabia/ que apesar da confusão entre prosa/ e poesia, isto não é a revolução. O que pesa/ é o salário que custeia a vida e a verdade é essa" ${ }^{15}$. Nessas condiçốes sociais e econômicas, nessas condiçóes culturais e vitais, se escrever é proibido, ler é igualmente algo que, desde cedo, não se deve aprender. Antes de ser uma luta contracultural daqueles que, por terem acesso à cultura, rebelaram-se contra aquilo que dela é opressivo, na vida do subúrbio a luta é pelo letramento, para aprender o que não se deve - ler - e fazer o que é proibido: escrever. E isso de tal modo que se enfrente justamente "[...] o poder// que é do outro/ e não meu" ${ }^{\text {. }}$. Na genealogia do poeta, os dois mandamentos opressivos de uma vida economicamente desfavorecida: não se pode escrever; não se deve ler.

13 Id.Ibid. p. 9.

14 Ibid.p. 9.

15 PINTO, André Luiz. Terno novo. Rio de Janeiro: Editora 7 Letras, 2012. p. 54.

16 Id.Ibid. p. 36. 
No poema "xxvi" do mesmo livro, surge um terceiro mandamento, para se juntar ao não se pode escrever e ao não se deve ler: não dever pensar. Esse poema faz surgir o terceiro mandamento, a terceira lei, a terceira ordem, a terceira imposição, a terceira restrição: "[...] você não sabe o que escreve,/ pensa que a imaginação decifra a dor/mas ela não decifra; você que nem devia/ ter pensado" 17 . Os poemas nos deixam saber as três leis, as três proibiçôes, as três restriçôes, as três imposições: não escrever, não ler, não pensar. Essas três proibiçōes, essas três restriçōes, instauram desde sempre um dano prematuro incontornável na vida de um poeta vindo do morro e do subúrbio, a herança política, econômica, social e cultural de um dano que o poeta terá de aprender a usar a seu favor. Nesse contexto, estando em sua gênese (e em sua ruína), contrariando proibições, restriçóes e deveres, ler, escrever e pensar, como um modo de garantir sua parcela pelo adentramento na linguagem e no discurso a se fazer ouvido, se coloca inevitavelmente de maneira política. Eis o nascimento do poeta, sua história biográfica, familiar, econômica e cultural, sua gênese, sua luta - de uma vida política pela escrita, pela leitura, pelo pensamento.

No meio da indecidibilidade e da indeterminaçâo de quem fala, aquele que, no poema, se refere ao poeta por "você" acrescenta: "[...] agora é assim:/ poetas sobem o morro, fazem suas pesquisas/ acham que a vida rude lhes inspira" ${ }^{18}$. Enquanto no poema "i”, com a avó e a mãe, o subúrbio se fazia o lugar de proveniência da família do poeta através de "Madureira, matadouro de homens", agora, no poema "xxvi", associado ao pai, é a vez do "morro", do morro que alguns poetas "agora" sobem para que a "vida rude" que lhes cabe lhes sirva igualmente de motivação para enfrentarem a morte e o interdito para, enfrentando o interdito e a morte, contra todas as proibições e restriçōes, ganharem palavras para lê-la, escrevê-la, pensá-la. Nesses versos, interessa-me o "agora", o "agora é assim", que determina esse novo modo poético e político de a poesia ser feita no subúrbio, no morro, no matadouro de vidas humanas, no meio do fogo cruzado, no meio da rudeza da vida. Nesse "agora", nesse "agora é assim", tem um ponto de virada histórico da poesia e da política, um ponto em que algo diferenciado acontece, um ponto em que aqueles que não eram para ler, para escrever, para pensar, aqueles que não podiam nem deviam escrever, ler nem pensar, pensam, leem, escrevem. No enfrentamento desse impasse, no enfrentamento dessa aporia, a requisiçáo do que Rancière chamou de "partido dos pobres" participando da contagem do povo, da "parte dos sem parcela"19 fraturando a totalidade imaginária do antipolítico

17 PINTO, André Luiz. Ao léu. Rio de Janeiro: Editora Bem-te-vi, 2007, p. 59.

18 Id.Ibid. p. 59.

19 RANCIÈRE, Jacques. O desentendimento; politica e filosofia. Tradução de Ângela Leite Lopes. São Paulo: Editora 34, 2018, p. 26. 
que náo reconhece sua existência e garantindo uma poesia eminentemente política exatamente no autobiográfico e familiar.

Volto ao poema:

Prazer, esse sou eu
filho de doméstica
numa época em que
patróes cismavam
em chamar de filhas
as mucamas. Eu
criado numa mansão
da Barra, obrigado a amar
patróes como avós
sem direito de herança.
Uma coisa aprendi:
a ler livros e a me irritar
com facilidade - lá, onde
o sinal está vermelho
e sempre acabo errando
a baliza - onde ninguém
divide nada, quando
até quem te chamou de sobrinho
diz um dia: a casa é nossa
deves partir. Tá bom, disse.
Só me dá duas semanas ${ }^{20}$.

Nele, A.L.P. cumpre o imperativo retornante que, em 2012, lançava sobre o outro no poema "Retorno": "olhe", "olhe a tua volta", "olhe ao redor", "olhe mais um pouco", "olhe, peço de novo", "olhe na hora", "olha bem de perto, você aguenta". Aguentar olhar o real o mais de perto possível, sustentando na linguagem do poema aquilo que ele pode suportar, aquilo que no limite ele é capaz de sustentar, aquilo que no extremo ele consegue sofrer do real encarado. O período entre 2012, ano da publicação de Terno novo, e 2016 (ano da publicação de Mas valia - e Nós, os dinossauros) é de extrema importância para a respectiva poesia, que consolida, cada vez com maior nitidez, uma aposta no sentido e na possibilidade de o poema dizer diretamente aquilo que necessita dizer. Há uma confiança no sentido passível de ser dito. O que "Prazer, esse sou eu" parece necessitar dizer?

20 PINTO, André Luiz. Mas valia. Rio de Janeiro: Editora 7Letras, 2016. p. 16. 
Ainda que responda a uma pergunta de toda uma vida, "Prazer, esse sou eu", o primeiro verso, indica que o poema é a realização de uma tentativa perseguida há pelo menos quatro anos. Como se apresentar aos leitores, a si e a quem quer que seja? Como dizer quem se é? Não é pouca coisa. Por fora dos clichês, não é nada fácil. É preciso uma obsessão imensa, mas não apenas isso. Na última das Norton Lectures, "O credo de um poeta", proferida em Harvard em 10 de abril de 1968, Borges diz se divertir com "a ideia de que, embora a vida de uma pessoa seja composta de milhares e milhares de momentos e dias, esses muitos instantes e esses muitos dias podem ser reduzidos a um único: o momento em que a pessoa sabe quem é, quando se vê diante de si”21. Ainda que no caso de A.L.P. não se trate de uma diversáo, a ideia em jogo no respectivo poema lida com esse instante singular em que finalmente "a pessoa sabe quem é, quando se vê diante de si". Sabendo pelo poema, no poema e na vida indiscerníveis quem se é, vendo-se pelo poema, no poema e na vida indistinguíveis diante de si, o poeta é capaz tanto de, apresentando-se, dizer quem é quanto de fazer dessa apresentação um envio necessário a um outro que se coloca simultâneo à apresentação de quem se é - porque se é desde sempre um outro -, um envio igualmente desse instante único que, de algum modo, ao dizer-se, diz exatamente por uma por uma ferida, por uma exclusão, por um trauma, toda uma vida, implicando todos os outros momentos vividos.

Como um poema de toda uma vida, buscado explicitamentepor pelo menos quatro anos, "Prazer, esse sou eu" tem um antecedente no livro que precede o de sua publicação: o segundo poema da série "Sete vezes", de Terno novo, começa dizendo "Esse homem sou eu"22. Sendo igualmente uma tentativa de dizer quem se é, "Esse homem sou eu" não traz, entretanto, a alteridade já no início de sua proferição pela apresentação implicada no "Prazer,"; além disso, nesse verso, ainda é preciso se designar enquanto "homem", seja para, em sentido restrito, diferenciar-se da mulher, seja, em sentido amplo, para se diferençar dos animais, vegetais, minerais, coisas... Enquanto "Esse homem sou eu" oferta, no próprio verso, alguma determinação ao "esse" - esse eu é o de um homem -, "Prazer, esse sou eu" resguarda uma indeterminação inicial ao pronome demonstrativo e ao "eu" com que o verso termina, fazendo com que, em sua calma maior para dizer quem se é, o que o determina venha em seguida, ao longo de todo poema. Para ganhar tal determinação, o leitor terá de seguir o poema até o último verso, surpreendente, espantoso, inesperado e necessário para compor esse que se apresenta indeterminadamente no primeiro verso.

21 BORGES, Jorge Luis. "O credo de um poeta". In: Esse ofício do verso. Organização de Calin-Andrei Mihailescu. Tradução de José Marcos Macedo. São Paulo: Companhia das Letras, 2007, p. 105.

22 PINTO, André Luiz. Terno novo. Rio de Janeiro: Editora 7Letras, 2012. p. 17. 
Para sua relação com "Prazer, esse sou eu”, há duas coisas a serem levadas em conta no poema " 2 " da série "Sete vezes". Eis o poema na íntegra: "Esse homem sou eu./ Primogênito de uma família/ de oito irmãos./ Pouco conto da vida, eu/ que sempre detestei/ a juventude./ Desconfio do mineral/ e da planta./ Não trago fé alguma./ Lavo os pés/ com ciúme./ O destino que havia/ escorreu./ Aranha fez ninho/ no meu nome." ${ }^{23}$ Em uma rápida leitura dele, poderia dividi-lo em duas partes: a primeira, com os seis versos iniciais; a segunda, indo do sétimo ao décimo quinto verso, o final. Mesmo que a autoapresentaçáo se faça do começo ao fim, parece-me haver uma mudança de tom nessas duas partes, já que, enquanto a primeira traz uma apresentação familiar e um modo de lidar diretamente com a vida vivida e vivível, na segunda, ainda que o poeta esteja implicado, há um deslizamento para minerais, plantas e temas mais indiretos, em que o sentido se torna progressivamente mais "disperso" e "fragmentado", como disse Eduardo Guerreiro do segundo livro do poeta ${ }^{24}$ e como, de alguma maneira, os outros três apresentadores dos outros três livros iniciais do poeta também disseram.

Nessa segunda parte, os dois verbos iniciais das duas primeiras frases ("desconfiar" e "trazer") ainda se remetem a esse homem que é o "eu" do começo do poema, enquanto na seguinte já há uma imagem gerada ("Lavo os pés/ com ciúme") que vai tornando o sentido mais opaco, passando pela frase seguinte, cuja nova metáfora nâo facilita mais a compreensão ("O destino que havia escorreu”), chegando ao verso final, que, ecoando muito de perto Manoel de Barros, é uma frase que instaura uma possibilidade sem qualquer referencialidade possível, ou seja, uma frase cuja poética está naquilo que só a linguagem é capaz de produzir ("Aranha fez ninho/ no meu nome"). Dentro do poema, ou mesmo por fora dele, mas por dentro da poemática de A.L.P., o que significa "lavar os pés/ com ciúme", ou que destino é esse que havia e escorreu? O que quer dizer a aranha fazer ninho do nome do poeta, senáo algo como os inutensílios ou brinquedos de palavras ou uma produção de linguagem tão afins aos do poeta sul-mato-grossense? Essa abertura e essa indeterminação dos sentidos, bem como esse autocolocar-se quase exclusivo da linguagem passam longe de "Prazer, esse sou eu", que se póe como outra tentativa, renovada, de apresentação do poeta.

Mesmo no que chamei de a primeira parte do poema, poderia fazer mais uma subdivisão estratégica, separando os três versos iniciais dos três seguintes. Isso para mostrar a segunda coisa importante a ser salientada em relação a "Prazer, esse sou eu". Se, resguardando as diferenças, os três primeiros versos do poema "2" se afinam ao poema posterior, os três seguintes ("Pouco conto da

23 Id.Ibid. p. 17.

24 GUERREIRO, Eduardo. “Casca de banana”.IN: Ao léu. Rio de Janeiro: Editora Bem-te-vi, 2007. p. 54. 
vida, eu/ que sempre detestei/ a juventude") me parecem trazer uma diferença significativa e outra pontual: 1) uma tática esperada do enfrentamento, da oposição, da reação ou da abominação ("sempre detestei/ a juventude"), da qual poderia ser indagado se ainda faz parte da própria juventude que deseja repelir, em contraposição, no caso do poema posterior, a uma estratégia da aquiescência com resultados inesperados; e, logo no começo, uma espécie de tentativa de determinar uma medida (o "Pouco") para o que conta da vida, enquanto em "Prazer, esse sou eu" haveria, para usar a mesma terminologia, um "contar" sem qualquer mensuração, uma aposta, sem qualquer afetação, nesse contar, apesar de tudo, tranquilo.

Com seu andamento cadenciado e confortável e com as duas frases mais breves sendo exatamente as conclusivas do poema, que também pelo ritmo diferenciado surpreendem imensamente, "Prazer, esse sou eu" tem pausas aos fins dos versos e enjambements intensivos a, pela expectativa criada pela interrupção do corte e a surpresa do que vem em seguida, aumentar a força do sentido que quer ser dito: "Prazer, esse sou eu/ filho de doméstica", "patrôes cismavam/ em chamar de filhas/ as mucamas" (assim como o enjambement, a inversão aqui também se mostra intensiva); "[...] Eu/ criado numa mansão/ da Barra"; "[...] obrigado a amar/ patróes como avós/ sem direito de herança"; "a ler livros e a me irritar/ com facilidade"; "e sempre acabo errando/ a baliza" 25 etc... Importante sinalizar que, com o poeta sendo "filho de doméstica", quando o poema afirma, no enjambement do sexto para o sétimo verso, "[...] Eu/ criado [...]", esse "criado" tem, obviamente, uma dupla função e um sentido duplo: como verbo, diz que o poeta foi "criado numa mansão/da Barra”, mas, como substantivo, é o poeta que, por ser filho de doméstica, se diz "criado", ou seja, empregado, reverberando sua condição a um só tempo de pertencimento e de não pertencimento à família em cuja mansão vive. Esse é o motivo pelo qual o poeta sempre acaba "errando" e, como o fim do poema, impelido a uma errância, aquiescida, nesse poema que poderia dizer tratar de uma poética do erro aquiescido, de uma poética da errância aquiescida derivada de uma poética do desabrigo.

Quanto à narrativa autobiográfica que se vai fazendo por dentro e por fora desse poema, é apenas porque a máe trabalha como empregada doméstica em uma mansão da Barra que ele, A.L.P., o poeta que escreve tudo isso, morando com a mãe na casa da família, é "criado" em uma mansão na Barra com a família que emprega a mãe e por essa família. Esse que é "criado" na família, com a família, por essa família, traz, com certeza, o sentimento ambíguo de ser, em algum momento, colocado em seu devido lugar, ou seja, como "criado" dessa família. Há todo um jogo flutuante de

25 PINTO, André Luiz. Mas valia. Rio de Janeiro: Editora 7 Letras, 2016, p. 16. 
preposiçôes necessárias nesse imbróglio. Há uma reciprocidade controversa nessa relação antagônica: enquanto, seguindo a tradiçẫo escravocrata brasileira e suas derivaçóes modernas e atuais desdobradas nas relaçóes entre patrôes e empregadas domésticas, aqueles chamam "de filhas/ as mucamas", o poeta era "obrigado a amar/ patrôes como avós/ sem direito de herança" (reparem as duas quebras altamente intensivas aqui).

A um só tempo neto e sem direito de herança, sobrinho e criado, morador de uma mansão da Barra e carregador das marcas indeléveis do subúrbio e do morro, xucro e destinado à educaçáo com uma consequente aprendizagem, defendendo o poder do outro e sendo literalmente desabrigado e desamparado por esse outro poderoso, esgarçado nessa fratura, habitante dessa ferida, vivente desse hiato, o poeta consegue o que lhe era, a princípio, proibido: ler, escrever, pensar. Junto com ler (e, certamente, com escrever e pensar), ele consegue aprender uma irritação, cujo enjambment nos leva, no poema, a vincular à leitura: "Uma coisa aprendi:/ a ler livros e a me irritar/ com facilidade". Nesses versos e nesses cortes, há um paradoxo, uma estranheza criada com a maior das sutilezas. Ler livros e irritar-se são duas coisas, duas açôes, ou duas passividades, ou uma ação e uma passividade, ou duas passividades, ou uma ação e um medial, ou, talvez melhor, dois mediais (já que se irritar não é exatamente uma ação, mas o efeito de uma ação sofrida e ler parece ser igualmente ser lido)... Em todo caso, ler livros e irritar-se são duas coisas, não uma, garantidas pela conjunção aditiva. Sendo duas coisas, e não uma, por que, então, o poema afirma "Uma coisa aprendi" e não "Duas coisas aprendi"? O poeta diz ter aprendido "uma coisa" que, entretanto, são duas. Como lidar com esse impasse? O que está em questão é que ler livros e se irritar estáo interligados, fazendo parte de um mesmo processo de elucidação da situação pessoal, familiar, cultural, social e política que se vive. Lendo, toma-se consciência do que se vive. Lendo e tomando consciência do que se vive, é possível, no lugar de "sair à defesa do poder// que é do outro/ e não meu"26, reverter, de algum modo, o processo. O difícil é saber em que consiste essa reversão. É possível ir contra o poder que é do outro sem ser reativo? É possível sair em defesa do próprio poder impotente sem ocupar o lugar que os poderosos ocupam?

A reversão realizada em "Em família” é imensa. Em "Em família”, há uma cena re-construída. A avó que o criou como pertencente à família está morta. O poema é direcionado a ela, destinatária das palavras ("Tenho certeza/ que o poema/ chega a ti", "Vou contar tudo, vó"). Conta-se os últimos dias da avó, o dia do velório ("do velório que esperava náo fosse o teu”) e do enterro, no qual há um acontecimento desconcertante, doloroso, sofrido,

26 PINTO, André Luiz. Terno novo. Rio de Janeiro: Editora 7Letras, 2012. p. 36. 
que, por inesquecível, atualizando os efeitos de um trauma, é necessário retirar do esquecimento. Em tal série, não se trata de que o poeta fora "criado numa mansão/ da Barra, obrigado a amar/ patróes como avós/ sem direito de herança", mas, antes, de assegurar que "Dona Leda [...]/ amava mais um estranho/ que netos e sobrinhos", que "Dona Leda/ [...] amava/ mais um estranho que netos legítimos", de assegurar que "Sentei a seu lado [ao lado de Dona Leda]/ e não vocês. Ela disse/ que me amava mais que tudo/ e vocês não". Há um hiato entre o modo de lidar com o amor nos dois poemas. Mesclados ao autobiográfico, em um o tom fortemente político da obrigação do poeta de, desde pequeno, ter de "amar/ patróes como avós/ sem direito de herança", em outro o asseguramento de, diante do ocorrido no velório, ser ele, o neto ilegítimo, o neto bastardo, o estranho, o foco do amor da avó, o escolhido pela avó, o eleito pela avó. No lugar da avó morta, pela avó, ele dá o testemunho do amor da avó por ele e da ausência de amor da avó pelos outros sobrinhos, netos e outros membros da família.

Por amar mais um criado na e da casa, por amar mais um filho da doméstica, por amar mais um estranho do que netos e sobrinhos legítimos, por amar mais esse intruso do que todos e tudo, por amar mais esse neto ilegítimo do que os descendentes de sangue, por amar mais esse neto bastardo do que todos os outros e todas as outras da família, por tal "infâmia", Dona Leda recebe o estigma de, do ponto de vista da família, ser vista como quem "não valia a pena", como quem "não valia nada", tal repetido no poema pelo tom sarcástico e revanchista do poeta, que, enfrentando a situação, faz seu acerto de contas. A diferença central é que, na série, ele não era o obrigado a amar os patróes como avós; pelo ponto de vista assumido do próprio poeta que testemunha por ele e pela avó, ele era o verdadeiramente amado pela avó. Há o poema central de "Em família", em que o poeta abre dizendo "Vou contar tudo, vó", que nos dá a ver o drama que prepara "Prazer, esse sou eu", com, aparentemente, a mesma personagem incluída, a tia, chamada por um pseudônimo, o de Cláudia. $\mathrm{O}$ poema é endereçado à falecida como quem, endereçando-se a um morto, se endereça à autoridade da sinceridade maior incorruptítvel, pois, entre os sobreviventes da família, é apenas a ela, que o amou, que agora ao neto importa falar. E, por fora da família, a todos nós, leitores, a quem dá o testemunho de sua dor. Convocando o espírito da avó e sendo destinado a ela e ao amor que ela sentiu pelo neto ilegítimo, o poema assegura a legitimidade desse amor na legitimidade do poema. O grande feito é que o tido por ilegítimo parece ser de fato o mais legítimo de todos.

O fortíssimo poema "v" de "Em família" conta a cena que antecede a de "Prazer, esse sou eu": "Vou contar tudo, vó./ Convoco tua imagem como se convoca/ um espírito. No velório, Cláudia, tua sobrinha disse/ que devo pedir licença/ não somos mais neto \& avó. Tenho certeza/ que não há juiz que 
condene/ tal metafísica, desejo mais atormentado/ que essa fé. Esperávamos de Cláudia a oração./ Foi quando Cláudia disse: 'estamos aqui/ no velório de Leda Coelho/ de Faria Rocha./ Infelizmente não puderam comparecer/ (como os hipócritas lembram sempre deputados/ de plantâo) seus netos \& filhos/ restando apenas/ Amigos \& Sobrinhos'/ (Pausa Para Cuspir)"27. Presente no velório, o poeta é desconsiderado por Cláudia como membro da família, como neto; Cláudia, que deveria ter feito uma oração, acaba por fazer uma ofensa irreparável, tratando o único neto presente ao velório como ilegítimo, como, agora que a avó está morta, não pertencente à família, como, tal o poema anterior na série afirma, "agora exigem licença/ que te chame de vó" ${ }^{28}$, como não sendo neto, já que, na presença do poeta, ela diz que "netos \& filhos" náo puderam comparecer ao velório. Com seu amor assegurado por sua relação direta com a avó, de cujo amor por ele o poema dá testemunho, o neto tido por ilegítimo, mostrando sua legitimidade também por ser o único presente no velório, vinga-se da exclusão sofrida. No poema, interrompendo a fala de Cláudia, chama-a de hipócrita, compara-a a deputados de plantão; interferindo na fala de Cláudia, insere o " $\&$ " - ou seja, o "e" empresarial e comercial usado duas vezes - no lugar do "e", e as maiúsculas de "Amigos \& Sobrinhos"; coloca os parênteses finais e as maiúsculas, como anteriormente mencionado, em "(Pausa Para Cuspir)", tratando irônica e sarcasticamente a família como uma empresa e o seu respectivo amor como meramente comercial. Diante desse poema decisivo, uma passagem já mencionada do último poema dessa série reverbera seu duplo sentido: "Sentei a seu lado [ao lado de Dona Leda]/ e não vocês. Ela disse/ que me amava mais que tudo/ e vocês não"29. Esse "e vocês não" diz que Dona Leda amava o poeta mais que tudo e não amava "vocês", os legítimos da família? Esse "e vocês náo" diz que, enquanto dona Leda amava o neto tido por ilegítimo mais que tudo, os outros membros da família, o "vocês", não o amavam, como fica claro na "oração" de Cláudia no velório? $\mathrm{Na}$ amplitude do poema, as duas leituras são, certamente, possíveis e, mesmo, necessárias. Nesse "e vocês não", há igualmente um paralelismo invertido, que ele vem reforçar, já que do mesmo modo que fora o neto tido por ilegítimo quem se sentou ao lado da avó "e não vocês", fora ela quem disse "que me amava mais que tudo/ e vocês não". Repito a passagem para dar mais visibilidade ao paralelismo invertido no jogo das palavras: "Sentei a seu lado [ao lado de Dona Leda]/ e náo vocês. Ela disse/ que me amava mais que tudo/ e vocês não".

27 Id.Ibid. p. 55.

$28 \mathrm{Ibid}$. p. 54.

29 Ibid. p. 62. 
Neste poema em que os cortes e enjambements são intensivos, há ainda um corte a se sobrepor a todos os outros. Quando a suposta tia, aquela que, antes, enquanto a avó especificamente e os avós eram vivos, "até" chamara o poeta de "sobrinho", agora, mostrando que, desde ao menos a morte da avó (se levarmos em conta "Em família"), nada mais será compartilhado nem dividido com o estranho dentro da familha, com o "criado" intruso no seio da familha rica, com o bastardo infiltrado na mansão familhar, lhe diz, a esse que também morava na mansão com os avós como neto destes: “[...] a casa é nossa/ deves partir". Colocando a aporia autobiográfica e política maior, o veredito se parte no meio do que ele anuncia, fazendo tudo se partir: o veredito (com quatro sílabas antes da quebra e quatro depois), a antiga família, o ilegítimo... Só Cláudia não se parte, só Cláudia resta inteira, total, una, indivisível, certa, poderosa, resguardando pela força sua legitimidade e assegurando a integridade sanguínea da familha. O poeta parte e, partido, assume a ordem que lhe é dada de partir, evidenciando, com a assunção de sua impotência, o modo perverso de o poder se realizar em seu extremo: "[...] Tá bom, disse./ Só me dá duas semanas". Com essa singeleza e humildade, com essa aquiescência inesperada e espantosa, o poeta parte, partindo o próprio veredito no poema que faz de sua vida, no poema que faz sua vida. E muito da nossa. E muito da nossa história, da nossa cultura, da nossa política, da nossa economia, das nossas relaçóes sociais... 


\section{Referências}

BORGES, Jorge Luis. "O credo de um poeta”. In: Esse oficio do verso. MIHAILESCU, Calin-Andrei (Org.). Tradução de José Marcos Macedo. São Paulo: Companhia das Letras, 2007.

PINTO, André Luiz. Flor à margem, Rio de Janeiro: Produção independente, 1999.

PINTO, André Luiz. Primeiro de abril. São Paulo: Editora Hedra, 2004.

PINTO, André Luiz. Isto. Belo Horizonte: Espectro Editorial, 2005.

PINTO, André Luiz. Ao léu. Rio de Janeiro: Editora Bem-te-vi, 2007.

PINTO, André Luiz. Terno novo. Rio de Janeiro: Editora 7Letras, 2012.

PINTO, André Luiz. Mas valia. Rio de Janeiro: Editora 7Letras, 2016.

PINTO, André Luiz. Nós, os dinossauros. São Paulo: Editora Patuá, 2016.

PINTO, André Luiz; FLORES, Guilherme Gontijo; AQUINO, Mônica. Poemas. Sáo Paulo: Editora Quelônio, 2018.

PLAQUETE do ciclo Vozes, Versos, organizado por Tarso de Melo e Heitor Ferraz.

RANCIÈRE, Jacques. O desentendimento; politica e filosofia. Tradução de Ângela Leite Lopes. São Paulo: Editora 34, 2018.

Alberto Pucheu. Professor de Teoria Literária do Departamento do Programa de Pós-Graduação em Letras (Ciência da Literatura), da Universidade Federal do Rio de Janeiro. Bolsista de Produtividade em Pesquisa do CNPq e Cientista do Nosso Estado da FAPERJ.

E-mail: apucheu@gmail.com 